\title{
Self-efficacy in Teamwork and Entrepreneurship in University Students from Social and Health Sciences Programs
}

\author{
Dr. Fernando Mondaca, \\ Dr. Carolina Jiménez Lira, \\ Dr. Susana Ivonne Aguirre, \\ Dr. Raúl Josué Nájera, \\ Dr. Ma. Concepción Soto, \\ Martín Alonso González, M.C \\ Dr. Yunuen Rangel Ledezma, \\ Autonomous University of Chihuahua, Mexico
}

\begin{abstract}
The purpose of the present descriptive study is to compare the profiles of perceived self-efficacy in teamwork and entrepreneurship between Health Sciences and Social Sciences university students. The total sample consists of 972 participants: 484 from the Health Sciences and 488 from the Social Sciences programs, with an average age of 18.68 years $(\mathrm{SD}=1.52)$ and 18.48 years $(\mathrm{SD}=1.26)$ respectively. A quantitative approach with a descriptive and transversal survey design was used. All the participants completed the Selfefficacy Teamwork and Entrepreneurship Scale. The results of the one-way multivariate analysis of variance, followed by one-way univariate analysis of variance, showed that the Social Sciences students reported statistically significant $(\mathrm{p}<.05)$ better perceived self-efficacy, desired self-efficacy and reachable self-efficacy in teamwork than the Health Sciences participants, while the students of health sciences are perceived with a greater possibility of improvement in their perceived self-efficacy. Regarding the entrepreneurship factor, the Social Sciences students reported statistically significant greater perceived self-efficacy, desired and reachable self-efficacy than their Health Sciences counterparts $(\mathrm{p}<.05)$.
\end{abstract}

Keywords: Self-efficacy, beliefs, teamwork, entrepreneurship 


\section{Introduction}

Self-efficacy consists of personal judgements about how capable one is to achieve a goal or task (Bandura, 1997). That is, the belief in personal abilities and skills in determined physical, psychological, cognitive situations (Ornelas, Blanco, Gastélum \& Chávez, 2012; Schmidt, Messoulam \& Molina, 2008), based on previous results (Hernández \& Barraza, 2014). Achieving a task influences the selection of posterior activities due to the knowledge of the required effort and perseverance in activities with a greater level of difficulty, in other words, the relationship between the cognitive, psychological, and action domains with the interaction of emotions and thoughts (García et al., 2016; Gutiérrez, Escarti, \& Pascual, 2011).

Perceived self-efficacy influences a person's cognitive, psychological, motivational, affective, and physical domains. In the educational ambit, perceived self-efficacy supports academic development, regulation of learning and the search for personal and collective success (Bandura, 1993), goals, aspirations, results, perception of obstacles and opportunities (Bandura, 1997). Self-efficacy beliefs are necessary for performing academic activities given that students who trust their capabilities feel more motivated to reach their goals (Blanco, 2010; Rodríguez, 2009).

Self-efficacy collaborates with teamwork because confidence in abilities and capabilities produces a positive effect in learning environments among peers that is, during teamwork due to the perceived collaboration among fellows, generating a social self-efficacy. In addition, if a person who is part of a team exhibits characteristics of an entrepreneur, it is easier for him or her to develop in such environment. Entrepreneurs exhibit higher selfefficacy than the rest of the team members who can, however, develop the skills during the time they work together (Dunbar, Dingel, Dame, Winchip, \& Petzold, 2018). Given that self-efficacy is related to the emotional domain, people remember prior obtained results and compare the goals achieved by others to their own accomplishments, they assess information about their own capabilities and risk taking (Véliz, Droner, \& Sandova, 2016).

A belief in self-efficacy influences perception and assimilation of environment demands or threats. With low self-efficacy, the person exhibits a lack of control in encountered situations. On the other hand, a person with high self-efficacy can handle environmental stressors, and can control and manage a task adequately. In the academic environment, low self-efficacy is related to high levels of anxiety together with symptoms of stress. However, higher selfefficacy is associated to lower levels of discomfort, anxiety, and stress. Therefore, the use of learning tools and/or strategies are also influenced by personal beliefs (Cabanach, Valle, Rodríguez, Piñero, \& González, 2010).

Confidence in organizational skills to produce adequate results allows the goal to be achieved, provided that the appropriate methodology is 
employed. For example, the level of confidence that a student presents for completing schoolwork is related to the level of stress as well as to the active participation and lines of action the student chooses to use, all influenced by the ability to adapt to school requirements (Barraza \& Hernandez, 2015). Confidence levels are also positively associated to age because of the positive perception of the individual capabilities to meet the university requirements (Veliz-Burgos \& Apodaca, 2012). Another factor related to confidence levels and self-efficacy is the academic offer, for example, students who are completing their degrees on-line tend to dislike teamwork more than students who physically attend the institution where a high level of self-efficacy exists in teamwork (Konak, Kulturel-Konak, \& Cheung, 2018).

Self-efficacy, in combination with a pro-social behaviour and empathy influences responsibility, with which it adds to success of the activities that are chosen (Gutiérrez et al., 2011). The combination of self-efficacy and entrepreneurship produce characteristics such as extroversion, consciousness and openness towards new activities (Huszczo \& Endres, 2017).

Entrepreneurship and self-efficacy are related to university students' success given the interaction with academic, career, and life benefits. This is because the desires, academic and/or labor performance are constantly kept in mind together with an adequate capacity to confront and succeed, by means of adaptability and persistence when faced with a challenge (Nguyen, 2016). Among the challenges, outdoor activities have been found to foster skills of team work, enjoyment and self-efficacy in team work, these skills can transfer to university learning environments, academic, and personal performance (Cooley, Burns, \& Cumming, 2016; Dunbar et al., 2018).

Entrepreneurship can be directive or non-directive, both types influence others depending on their communication with the team members. When there is feedback between the entrepreneur and the team, there is a stronger relationship among participants (Campbell \& Lam, 2019). The choice of tools, lines of action, commitment, effort, and perseverance when facing conflict influences perceived self-efficacy. An increase in the sensation of self-efficacy is related to more affect, physical well being and better selection of future actions (Sansinenea et al., 2008), that is, an adequate social, academic, and psychological domain (Soria, Werner, Roholt, \& Capeder, 2019).

The present research is fundamentally descriptive and attempts to compare self-efficacy profiles in the domain of teamwork and leadership in university students from the Social Sciences and Health Sciences programs. 


\section{Method \\ Participants}

A total of 972 students from Autonomous University of Chihuahua, Mexico were included in the present study. Four hundred and eighty-eight students from the Social Sciences program and 484 from Health Sciences. Participant age ranged from 17 to 26 years; $M=18.48 \pm 1.26$ for the Social Sciences Program students and $M=18.68 \pm 1.52$ for the Health Sciences students. Convenience sampling was used while trying to obtain representativity of the different undergraduate programs offered by the university within the Social Sciences and Health Sciences areas.

\section{Instrument}

The Self-efficacy Teamwork and Leadership Scale is a computer assisted Likert-type questionnaire which includes 16 items to which students respond on a scale of 0-10 (Gastélum, Guedea, Viciana y Peinado, 2012). Questions refer to how capable he or she feels, how interested he or she is, and whether he or she would make an effort to change how capable he or she would be on each of the items (domains) corresponding to each of the competences (scale factors) Entrepreneurship and Teamwork (Figure 1).

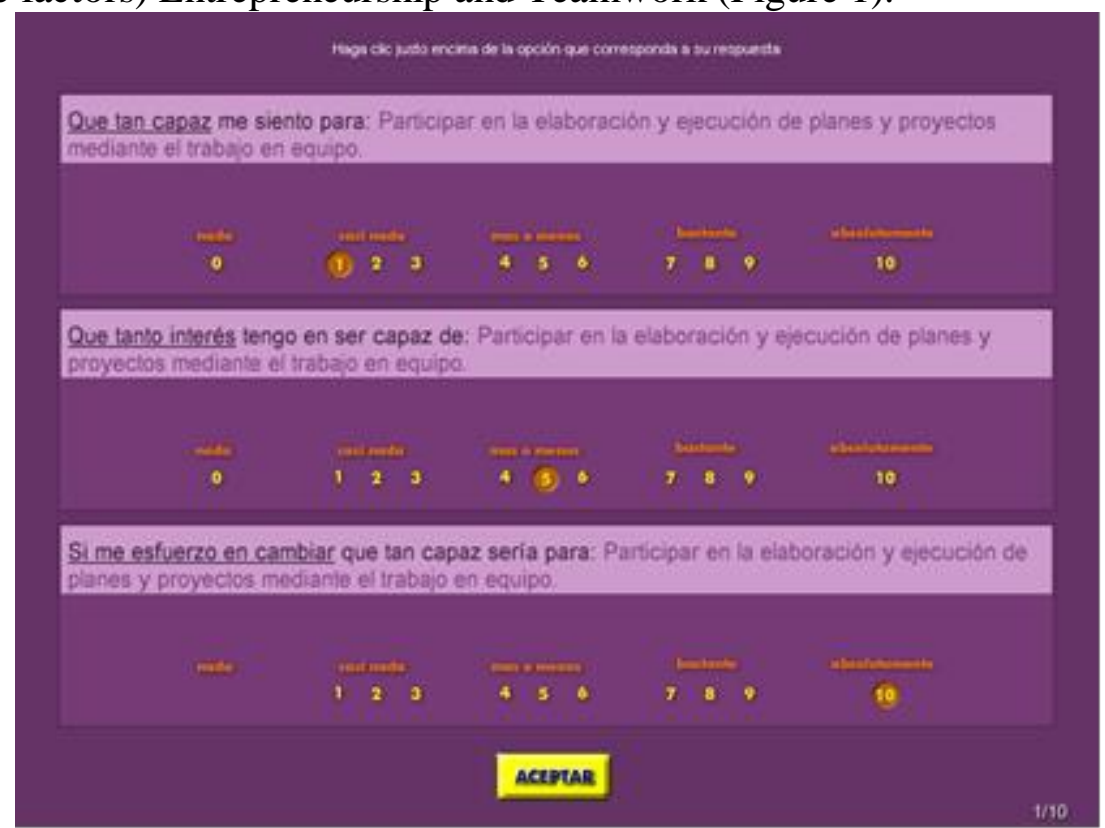

Figure 1. Example of responses for each questionnaire item.

Four indices were obtained from the answers:

1. Currently perceived self-efficacy.- obtained from the answers to the current scenario.

2. Desired self-efficacy.- obtained from the answers to the ideal scenario. 
3. Obtainable self-efficacy.- obtained from the answers to the change scenario.

4. Possibility of improving perceived self-efficacy.- obtained from the difference between index 3 and 1 (change minus current).

The 16 questionnaire items (Table 1) are grouped into two factors: teamwork (8 items) and entrepreneurship (8 items) on which larger numbers represent higher levels of perceived, desired and obtainable self-efficacy.

Table 1. Items of the Self-efficacy Teamwork and Entrepreneurship Scale grouped by factors

\begin{tabular}{|c|c|c|}
\hline Factor & Ite & \\
\hline \multirow[t]{8}{*}{ Teamwork } & 2 & $\begin{array}{l}\text { Demonstrate capacity to generate employment and self- } \\
\text { employment. }\end{array}$ \\
\hline & 4 & Optimize the use of the existing resources. \\
\hline & 6 & $\begin{array}{l}\text { Use the principles of strategic management principles in } \\
\text { project development. }\end{array}$ \\
\hline & 8 & $\begin{array}{l}\text { Apply methods to promote, execute and evaluate the impact of } \\
\text { a project. }\end{array}$ \\
\hline & 10 & Link the academic environment to the work environment. \\
\hline & 12 & Create and innovate. \\
\hline & 14 & Generate and adapt new technologies in my area. \\
\hline & & $\begin{array}{l}\text { Employ procedures when operating basic technology } \\
\text { equipment. }\end{array}$ \\
\hline \multirow[t]{8}{*}{ Entrepreneurship } & 1 & $\begin{array}{l}\text { Participate in the development and execution of plans and } \\
\text { projects by means of teamwork. }\end{array}$ \\
\hline & 3 & $\begin{array}{l}\text { Obey and ensure the obedience of the norms and laws } \\
\text { established in a social context. }\end{array}$ \\
\hline & 5 & Interact with multidisciplinary groups. \\
\hline & 7 & Identify leadership skills and group development potential. \\
\hline & 9 & $\begin{array}{l}\text { Develop and stimulate a culture of teamwork towards the } \\
\text { accomplishment of a common goal. }\end{array}$ \\
\hline & & $\begin{array}{l}\text { Show respect, tolerance, responsibility and openness to } \\
\text { confrontation and plurality in when working in group. }\end{array}$ \\
\hline & & $\begin{array}{l}\text { Respect, tolerate, and be flexible towards divergent lines of } \\
\text { thought in order to reach agreements by consensus. }\end{array}$ \\
\hline & & $\begin{array}{l}\text { Identify diversity and contribute to personal and group } \\
\text { conformation and development. }\end{array}$ \\
\hline
\end{tabular}




\section{Design}

Regarding the design of the study, a quantitative approach was used with a survey like descriptive and cross-sectional design (Hernández, Fernández, \& Baptista, 2014). The independent variable was Type of Undergraduate Program (Social Sciences and Health Sciences) and the dependent variable was the average of the scores obtained from the four indices for the factors Teamwork and Entrepreneurship.

\section{Procedure}

Students from the Social Sciences and Health Sciences undergraduate programs offered at the Autonomous University of Chihuahua were invited to participate. Those who agreed to take part in the study signed the corresponding informed consent form. The instrument, described above, was then completed by means of a personal computer (instrument management module from the typical execution scale editor) in a single session which lasted approximately thirty minutes conducted in the University computer labs.

At the beginning of each session, an introduction regarding the importance of the research and how to access the instrument was presented to the participants. Maximum honesty was requested from the participants who were ensured the confidentiality of the obtained data. The instructions on how to respond were presented on the first screens prior to the first instrument item. At the end of the session, students were thanked for their participation. Once the instrument had been applied, results were collected using the resultgenerating module of the scale editor version 2.0 (Blanco et al., 2013).

\section{Data analysis}

Descriptive statistics (means and standard deviations) for all the variables were calculated and are presented in Tables 2 (Teamwork) and 3 (Entrepreneurship). Subsequently, after verifying that the data met the assumptions of parametric statistical analyses, to examine the differences between the Health and Social Sciences students in both the reported selfefficacy in teamwork and entrepreneurship scores a one-way multivariate analysis of variance (MANOVA) was performed; results were followed up by the one-way univariate analyses of variance (ANOVAs). The effect size was estimated using the eta-squared $\left(\eta^{2}\right)$. All statistical analyses were performed using the SPSS version 21.0 for Windows. The statistical significance level was set at $p<.05$.

\section{Results}

\section{Teamwork factor}

Table 2 shows the results from the multivariate and univariate analyses of variance for self-efficacy for the factor teamwork. Results from the 
MANOVA showed statistically significant differences on the self-efficacy scores for the factor teamwork by type of undergraduate program (Wilks' $\lambda=$ $\left..958 ; p<.001 ; \eta^{2}=.042\right)$. Results from the ANOVAs showed that Social Sciences students reported higher perceived self-efficacy $(F=38.820, p<$ $.001)$, desired self-efficacy $(F=31.467, p<.001)$ and obtainable self-efficacy $(F=28.974, p<.001)$ than students from the Health Sciences programs with the latter showing a greater possibility of improving their perceived selfefficacy $(F=5.767, p<.05)$.

Table 2. Results from the MANOVA for the type of program differences in the four variables of self-efficacy for teamwork

\begin{tabular}{lccccc}
\hline & $\begin{array}{c}\text { Social } \\
\text { Sciences } \\
(n=488)\end{array}$ & $\begin{array}{c}\text { Health } \\
\text { Sciences } \\
(n=484)\end{array}$ & $F$ & $p$ & $\eta^{2}$ \\
\hline Perceived self-efficacy & $8.24(0.86)$ & $7.83(1.18)$ & 38.820 & $<.001$ & .038 \\
Desired self-efficacy & $9.02(0.82)$ & $8.66(1.17)$ & 31.467 & $<.001$ & .031 \\
Obtainable self-efficacy & $9.25(0.66)$ & $8.95(1.03)$ & 28.974 & $<.001$ & .029 \\
$\begin{array}{l}\text { Possibility for improving } \\
\text { perceived self-efficacy }\end{array}$ & $1.00(0.65)$ & $1.11(0.82)$ & 5.767 & $<.05$ & .006 \\
\hline
\end{tabular}

Note. Descriptive values are presented as mean (standard deviation)

\section{Entrepreneurship factor}

Table 3 shows the descriptive statistics for the self-efficacy variable for Entrepreneurship as well as the results from the multivariate and univariate analyses of variance. Results from the MANOVA showed overall statistically significant differences by type of undergraduate program on the self-efficacy scores for Entrepreneurship (Wilks' $\lambda=.967 ; p<.001 ; \eta^{2}=.033$ ). Subsequent ANOVA results showed that Social Sciences students reported higher perceived self-efficacy $(F=21.558, p<.001)$, desired self-efficacy $(F=$ $32.008, p<.001)$ and obtainable self-efficacy $(F=22.388, p<.001)$ than students from the Health Sciences programs with no significant differences regarding the possibility of improving their perceived self-efficacy. 
Table 3. Results of MANOVA for the type of program differences in the four variables of self-efficacy for entrepreneurship

\begin{tabular}{lccccc}
\hline & $\begin{array}{c}\text { Social } \\
\text { Sciences } \\
(n=488)\end{array}$ & $\begin{array}{c}\text { Health } \\
\text { Sciences } \\
(n=484)\end{array}$ & $F$ & $p$ & $\eta^{2}$ \\
\hline Perceived self-efficacy & $8.01(1.01)$ & $7.66(1.32)$ & 21.558 & $<.001$ & .022 \\
Desired self-efficacy & $8.99(0.84)$ & $8.60(1.25)$ & 32.008 & $<.001$ & .032 \\
Reachable self-efficacy & $9.17(0.72)$ & $8.88(1.10)$ & 22.388 & $<.001$ & .023 \\
$\begin{array}{l}\text { Possibility for improving } \\
\text { perceived self-efficacy }\end{array}$ & $1.15(0.76)$ & $1.22(0.96)$ & 1.470 & $>.05$ & .002 \\
\hline
\end{tabular}

Note. Descriptive values are presented as mean (standard deviation)

\section{Discussion and Conclusion}

Considering that self-efficacy is a predictive of academic performance (Ugur, 2015; Doménech-Betoret, Abellán-Roselló, \& Gómez-Artiga, 2017; Manzano-Sanchez, Outley, Gonzalez, \& Matarrita-Cascante, 2018; Korkmaz, Ilhan, \& Bardakci, 2018; Ayllón, Alsina \& Colomer, 2019; Maliha, \& Sarwat, 2019) this study was conducted with the aim of compare the profiles of perceived self-efficacy in teamwork and entrepreneurship between Health Sciences and Social Sciences university students

From the findings of this study the students from the social sciences programs perceived themselves as having higher self-efficacy than students from the Health Sciences programs; and those differences were statistically significant. Those results are like the reported from Odaci (2013), but different to findings from Ashrafi-Rizi, Najafi, Kazempour, \& Taheri (2015) and Tiyuri et al. (2018), in studies comparing self-efficacy in students of different schools.

Researching about teamwork and entrepreneurship factors is an important and actual topic, because the Teamwork factor is a significantly not developed competence in university education (Zavala, Flores, Meneses \& Hernández, 2018). At the same time, there is an actual need for research the entrepreneurship factor outside of entrepreneurial contexts (Newman, Obschonka, Schwarz, Cohen, \& Nielsen, 2019); as for Health and Social's Sciences in the present study.

Finally, seems that both programs receive students whose selfefficacy, while different, is comparable. However, about that point, the measurement instrument is based on self-report and thus may be biased due to social desirability issues (Rosenman, Tennekoon, \& Hill, 2011; Althubaiti, 2016). 
In conclusion, for the factor teamwork which refers to being able to respect, tolerate, and be flexible when faced with divergent lines of thought in order to reach agreements by consensus; interact with multidisciplinary groups; identify leadership skills and group development potential in addition to participating in the creation and execution of plans and projects as a team; the students from the social sciences programs perceived themselves as having higher self-efficacy, at the same time, with greater possibility and need to be more self-effective than students from the Health Sciences programs; and the latter with a greater possibility of improving their perceived self-efficacy.

On the other hand, for the entrepreneurship factor which refers to being able to demonstrate the capacity to generate jobs and self-employment; link academic and work environments; create and innovate; maximize the use of existing resources and using the principles of strategic management to develop projects, again, students from the Social Sciences programs perceived themselves as more self-efficient with a greater possibility and need to be more self-efficient than students from the Health Sciences programs.

Although the encountered differences when comparing self-efficacy profiles of students from the Social Sciences and Health Sciences programs were statistically significant, the size of the effect was small; we can thus state that perceived self-efficacy for the teamwork and entrepreneurship factors of students from the Social and Health sciences programs is pretty similar; the result is encouraging because it provides evidence that both programs receive students whose self-efficacy (with all its positive effects) is comparable.

In addition, that fact that the current, desired, and obtainable selfefficacy profiles show a similar trend (i.e., more perceived self-efficacy, more desire, and greater possibility to be effective) allows us to conclude that if a student improves on one of them, the others will improve as well.

Finally, taking into account that empirical research has shown in an ample manner, that self-efficacy is predictive of academic performance to a greater extent than other cognitive variables, that it predicts ulterior success, and that it is an important cognitive mediator between competence and performance as it favors cognitive processes, we can conclude that improving students' perception of being capable is a valuable educational goal, under the implicit notion that potentiating it will serve as a vehicle to improve other areas such as academic achievement and self-esteem.

In addition, we underscore the importance of increasing the amount of research on self-efficacy in Mexico given that most of the literature comes from other countries.

Finally, we acknowledge two limitations to the present research. First, participants were solely students, which limits the generalizability of the results. Enlarging the sample (including participants who are not students) is an area to be considered in future research. The second limitation comes from 
the measurement instrument which is based on self-report and thus may be biased due to social desirability issues.

\section{References:}

1. Althubaiti A. (2016). Information bias in health research: definition, pitfalls, and adjustment methods. Journal of multidisciplinary healthcare, 9, 211-217. doi:10.2147/JMDH.S104807

2. Ashrafi-Rizi, H., Najafi, NS., Kazempour, Z., y Taheri B. (2015). Research self-efficacy among students of Isfahan University of Medical Sciences. Journal of Education and Health Promotion. 4:26.

3. Ayllón, S., Alsina, Á., y Colomer, J. (2019). Teachers' involvement and students' self-efficacy: Keys to achievement in higher education. PLoS ONE 14(5): e0216865. https://doi.org/10.1371/journal.pone.0216865

4. Bandura, A. (1993). Perceived self-efficacy in cognitive development and functioning. Educational psychologist, 28(2), 117-148.

5. Bandura, A. (1997). Self-efficacy: The exercise of Control. New York: Freeman.

6. Barraza, A. y Hernández, L. F. (2015). Autoeficcia académica y estrés. Análisis de su relación en alumnos de posgrado. Revista electrónica diálogos educativos, 15(30), 21-39.

7. Blanco, Á. (2010). Creencias de autoeficacia de estudiantes universitarios: un estudio empírico sobre la especificidad del constructo. RELIEVE, 16(1), 1-28.

8. Blanco, H., Ornelas, M., Tristán, J. L., Cocca, A., Mayorga-Vega, D., López-Walle, J. y Viciana, J. (2013). Editor for creating and applying computerise surveys. Procedia Social and Behavioral Sciences, 106, 935-940. doi: 10.1016/j.sbspro.2013.12.105

9. Cabanach, R., Valle, A., Rodríguez, S., Piñeiro, I. y González, P. (2010). Las creencias motivacionales como factor protector del estrés en estudiantes universitarios. European Journal of Education and Psychology, 3(1), 75-87. doi: 10.1989/ejep.v3i1.47

10. Campbell, K. S. y Lam, C. (2019). The Effect of Leader RapportManagement Feedback on Leader-Member Relationship Quality and Perceived Group Effectiveness in Student Teams. IEEE Transactions on Professional Communication, 1-10. doi: doi: 10.1109/TPC.2019.2913238

11. Cooley, S. J., Burns, V. E. y Cumming, J. (2016). Using Outdoor Adventure Education to Develop Students' Groupwork Skills. Journal of Experiential Education, 39(4), 329-354. doi: https://doi.org/10.1177/1053825916668899 
12. Doménech-Betoret, F., Abellán-Roselló, L., \& Gómez-Artiga, A. (2017). Self-Efficacy, Satisfaction, and Academic Achievement: The Mediator Role of Students' Expectancy-Value Beliefs. Frontiers in psychology, 8, 1193. doi:10.3389/fpsyg.2017.01193

13. Dunbar, R. L., Dingel, M. J., Dame, L. F., Winchip, J. y Petzold, A. M. (2018). Student social self-efficacy, leadership status, and academic performance in collaborative learning environments. Studies in Higher Education, 43(9), 1507-1523.

14. García, J. M., Inglés, C., Días, A., Lagos, N., Torregrosa, M. y González, C. (2016). Capacidad predictiva de la autoeficacia académica sobre las dimensiones del autoconcepto en una muestra de adolescentes chilenos. Estudios sobre Educación I, 30, 31-50. doi: 10.15581/004.30.31-50

15. Gastélum, G., Guedea, J. C., Viciana, J. y Peinado, J. E. (2012). Composición Factorial de una Escala de Autoeficacia en el Ámbito del Trabajo en Equipo y Liderazgo en Universitarios de Ciencias de la Salud. Formación Universitaria, 5(4), 49-60. doi: 10.4067/S071850062012000400006

16. Gutiérrez, S. M., Escarti, A. E., y Pascual, B. C. (2011). Relaciones entre empatía, conducta prosocial, agresividad, autoeficacia y responsabilidad personal y social de los escolares. Psicothema, 23(1), 13-19.

17. Hernández, L. F. y Barraza, A. (2014). Autoeficacia académica percibida en la educación superior. REDIE, 6(10).

18. Hernández, R., Fernández, C. y Baptista, P. (2014). Metodología de la investigación. México: McGraw- Hill.

19. Huszczo, G. y Endres, M. L. (2017). Gender differences in the importance of personality traits in predicting leadership self-efficacy. International Journal of Training and Development, 21(4), 304-317.

20. Konak, A., Kulturel-Konak, S. y Cheung, G. W. (2018). Teamwork attitudes, interest and self-efficacy between online and face-to-face information technology students. Team Performance Management: An International Journal. doi: https://doi.org/10.1108/TPM-05-20180035

21. Korkmaz, O., Ilhan, T., y Bardakci, S. (2018). An investigation of selfefficacy, locus of control, and academic procrastination as predictors of academic achievement in students diagnosed as gifted and nongifted. European Journal of Education Studies, 0. Retrieved from https://oapub.org/edu/index.php/ejes/article/view/1678

22. Maliha, N., y Sarwat, I. (2019). Academic Self Efficacy as a Predictor of Academic Achievement of Students in Pre Service Teacher Training 
Programs. Bulletin of Education and Research. April 2019, Vol. 41, No. 1 pp. 33-42.

23. Manzano-Sanchez, H., Outley, C., Gonzalez, J. E., y MatarritaCascante, D. (2018). The Influence of Self-Efficacy Beliefs in the Academic Performance of Latina/o Students in the United States: A Systematic Literature Review. Hispanic Journal of Behavioral Sciences, 40(2), 176-209. https://doi.org/10.1177/0739986318761323

24. Newman, A., Obschonka, M., Schwarz, S., Cohen, M., y Nielsen, I. (2019). Entrepreneurial self-efficacy: A systematic review of the literature on its theoretical foundations, measurement, antecedents, and outcomes, and an agenda for future research. Journal of Vocational Behavior, 110(Part B), 403-419. https://doi.org/10.1016/j.jvb.2018.05.012

25. Nguyen, D. H. (2016). Student success through leadership selfefficacy: A comparison of international and domestic students. Journal of International Students, 6(4), 829-842.

26. Odaci, H. (2013).The Role of Computer Self-Efficacy, Self-Esteem, and Subjective Well-Being in Predicting Research Self-Efficacy among Postgraduate Students. Asia-Pacific Education Researcher, v22 n4 p399-406.

27. Ornelas, M., Blanco, H., Gastélum, G. y Chávez, A. (2012). Autoeficacia Percibida en la conducta Académica de Estudiantes Universitarias. Formación Universitaria, 5(2), 17-26. doi: 10.4067/S0718-50062012000200003

28. Rodríguez, M. N. (2009). Análisis factorial confirmatorio de la versión uruguaya de la escala Smart de Trapnell para medir capacidad intelectual percibida. Revista Iberoamericana de Diagnóstico y Evaluación Psicológica, 1(27), 85-105.

29. Rosenman, R., Tennekoon, V., y Hill, L. G. (2011). Measuring bias in self-reported data. International journal of behavioural \& healthcare research, 2(4), 320-332. doi:10.1504/IJBHR.2011.043414

30. Sansinenea, E., Gil, L., Agirrezabal, A., Larrañaga, M., Ortiz, G., Valencia, J. F. y Fuster, M. J. (2008). Autoconcordancia y autoeficacia en los objetivos personales: ¿Cuál es su aportación al bienestar? Anales de Psicología, 24(1), 121-128.

31. Schmidt, V., Messoulam, N. y Molina, F. (2008). Autoconcepto académico en adolescentes de escuelas medias: presentación de un instrumento para su evaluación. Revista Iberoamericana de Diagnóstico y Evaluación Psicológica, 1(25), 81-106.

32. Soria, K. M., Werner, L., Roholt, C. V. y Capeder, A. (2019). Strengths-based Approaches in Co-Curricular and Curricular 
Leadership: Opportunities to Magnify Students' Thriving. Journal of Leadership Education, 18(1), 11-132.

33. Tiyuri, A., Saberi, B., Miri, M., Shahrestanaki, E., Bayat, B. B., y Salehiniya, H. (2018). Research self-efficacy and its relationship with academic performance in postgraduate students of Tehran University of Medical Sciences in 2016. Journal of education and health promotion, 7, 11. doi:10.4103/jehp.jehp_43_17

34. Ugur, D. (2015). Student Engagement, Academic Self-efficacy, and Academic Motivation as Predictors of Academic Performance, The Anthropologist, 20:3, 553-561, DOI: 10.1080/09720073.2015.11891759

35. Veliz-Burgos, A. y Apodaca, P. (2012). Niveles de autoconcepto, autoeficacia académica y bienestar psicológico en estudiantes universitarios de la ciudad de Temuco. Salud \& Sociedad, 3(2), 131150.

36. Véliz, A., Droner, A. y Sandova, S. (2016). Relación entreautoconcepto, autoeficacia académica y rendimiento académico en estudiantes de salud de Puerto Montt, Chile. EDUCADI, 1(1), 97109. doi: 10.7770/EDUCADI-V1N1-ART1003

37. Zavala, L. E., Flores G. D., Meneses, G., J. H. V., y Hernández, V., I. A. (2018). Diagnóstico De Factores Conductuales Para El Trabajo En Equipo Con Estudiantes Universitarios. European Scientific Journal. 14, 19. ISSN: 1857 - 7881 (Print) e - ISSN 1857- 7431237 Doi:10.19044/esj.2018.v14n19p237

URL:http://dx.doi.org/10.19044/esj.2018.v14n19p237 